\title{
The application of reality simulators for improving the education quality at universities
}

\author{
Oksana Simonova ${ }^{1 *}$, Valentina Barashyan ${ }^{1}$, Artem Gampartsumov ${ }^{1}$, and Maria \\ Khlebnikova $^{1,2}$ \\ ${ }^{1}$ Rostov State Transport University, 344038, Rostov-on-Don, Russia \\ ${ }^{2}$ Don State Technical University, 344002, Rostov-on-Don, Russia
}

\begin{abstract}
The article touches upon the problem of necessity to change pedagogical methods and technologies in high school education that are determined by the changes in modern society. The authors point out that the up-to-date society is deeply plunged into digital technologies and the reality is that methods being used in education cannot meet the requirements of the present. In this regard the authors speculate that application of digital technologies, namely laboratory facilities of virtual reality in training process of technical university students is able to improve the education quality. The goal of this research is to prove this theory. The authors give a thorough comparative analysis of academic literature that describes the existing virtual reality facilities which are widely used in higher educational establishments of transport abroad as well as in the Russian Federation. The typology of training facilities is given in the article, all advantages and drawbacks of digital technologies concerning the virtual reality on the example of reality simulators railway complexes have been described. With the help of statistic data processing methods that have been obtained by the experimental way the authors have proved that the application of reality simulators laboratory facilities can improve the quality of training at technical higher educational establishments.
\end{abstract}

\section{Introduction}

The changes in the field of education as well as in other spheres of our up-to-date life are determined by the present developments in society which has been consumed by the universal digital technologies' diffusion. The characteristic of the "generation $\mathrm{Y}$ " or "millennials" as they are usually called is deep immersion into digital technologies. At the same time this part of young people is characterized by the impossibility to concentrate for a long time on the training process, which have been indicated by many researchers and various statistic data. This trend is well monitored all over the world. According to the data of Nielsen Global Survey, the $38 \%$ of all young people at the age of 15-20, for instance, are diverted on their smart gadgets while eating [1]. Besides of dangerous addiction this phenomenon negatively affects the whole education process when students can hardly

\footnotetext{
*Corresponding author: simnvoks@mail.ru
} 
concentrate on this or that subject. Thus, the generation of people constantly diverted on their smart gadgets has been grown up [2-3].

The necessity to respond the rapidly changing reality has been reflected also in the formation of the national program "The digital economy of Russian Federation" developed by the Russian government. The targets of this program include multilevel penetration of digitalization in all spheres of our government everyday life, namely:

- Digital environment

- Recruitment

- The formation of digital infrastructure

- Digital security

- Digital and informational technologies

- Digital management of the state.

The same goals are intended by the program "The digital school" which makes possible the modernization of the training process as well as it makes the up-to-date methods of training with the application of digital technologies available for schools.

Accordingly, moving with present time and following the need to meet its requirements, the training programs at high school must be subjected to the considerable changes in that field which touches upon the forms and methods of education, that means the essential increase of digital technologies share in the pedagogical repertoire of the lecturer. It is worth it to mention that skills of digital technologies application and digital literacy as a whole, are included into the list of skills drawn up by the P21(Partnership for $21^{\text {st }}$ Century Learning) [4] and being the obligatory condition of successful human individual existence in the society, according to the opinion of this organization members.

Let's make it clear that digital technologies of virtual reality or in other words reality simulators are included into the cross-cutting digital technologies as they are called in the national program "The digital economy of Russian Federation" and encourage to develop the informational support which allows to train up-to-date specialists.

The consideration of digital technologies applicable to the training process is not new and the use of training method with the application of virtual reality facilities has insufficiently been investigated, especially in the system of higher education, that in turn, makes this research as relevant as ever. Moreover, a lot of scientists and present-day researchers point out the positive dynamics increase while using immersive technologies, that are technologies of the immersion into the virtual reality, augmented reality and $360^{\circ}$ video [5-8].

The research of virtual environment and its influence on the quality of education is the theme of many investigations as beyond the Russian Federation so in the domestic scientific world. However, analyzing the up-to-date foreign sources concerning this problem we come to the conclusion that the most interest in analyzing virtual reality simulators and their influence on the quality of education has been in the fields of medicine, management and medical staff training. Thus, Mauriccio Pacilli and Simone Klarke are engaged in the research of simulation of pediatric surgery and its influence on the skills forming in the training process of pediatric surgeons [9]; Michael Crozier and Hither Ting are investigating simulators in the trauma surgeons training [10]; the group of specialists under the supervision of Martinou is engaged in the research of virtual reality simulators in the training of nursing staff [11]. A. Burden, P. Hallingerab, R. Wang are engaged in the development of programs with the virtual reality application in management $[12,13]$.

But the most interesting investigation for our research are the papers of Slovakian scientists under the supervision of Jurai Camaj devoted to the investigation of reality simulators applied for the engineering subjects training process at the technical universities [14]. The very important for our paper are also the developments of Swiss investigators from IMOB (The Institute of Transport Research) under the supervision of Dominike 
Ziemke concerning the effective approach to the scenario creation for the reality simulators in the field of transport [15]. Jazir Radianti and Tim Majchrzak are also investigating the immersive technologies of virtual reality [16], Jinksin Wang, Dineke E.H and Tigerlaa are researching the connection between motivation in learning and digital technologies, that is extremely significant for our paper [17]. In the Russian Federation the research of the virtual educational environment applied to the linguistics is carried out by I.V. Nefedov in the Southern Federal University [18]. Virtual reality in linguistics applied to the foreign languages study is also the subject of A. S. Bahmudova and A.D. Bahmudova investigations [19]. K. A. Fedorov and A. L. Nikonorov cover the methodology of hybrid virtual reality in the educational process [20].

As a result of carried out analysis of the domestic and foreign scientific literature the authors have assumed that the application of virtual reality laboratory facilities in the training process considerably increases the quality of education at higher educational establishments. The aim of our research is to prove the positive impact of technologies application and methods of virtual reality in the process of engineering profiles teaching. In order to confirm this hypothesis, the authors have used the following methods: the empirical method of comparison, the method of experiment, the method of testing, the theoretical method of analysis and modelling, the statistics mathematical method.

\section{Material and methods}

The simulators of reality nowadays are widely used not only in the entertainment sphere, but also in education, particularly in the training of railway specialists at technical universities, this is the subject of our research. If we consider the application of virtual reality methods in the field of illustrative approach in education it becomes clear that immersive technologies are best suited to the knowledge transfer and learning as they affect the sensor modality of humans allowing them to see, hear, taste the modelling objects and situations in training. Thus, the laboratory facilities of virtual reality at technical universities of transport are becoming more and more popular. The Slovakian scientists Jurai Camaj and Martin Kendra from the university in the town of Zilina describe the typology of virtual reality simulators laboratory facilities based on the following division of the virtual complexes in the training process of manipulations in the virtual logistics center of transport terminal:

- The simulators of the marshalling yard

- The simulators of the intermodal terminal

- The simulators of the shunting work at warehouses

Jurai Camaj and Martin Kendra point out that the simulators of the transport terminals allow to practice the majority of the operations connected with the work organization on the railway and the transportation management process [14].

The group of Swiss scientists under the guidance of D. Ziemke describe the classification of the reality simulator on the base of the effective approach development to the establishing of the agent - based transport scenarios on the base of the large field data array. They describe such reality simulators for transport as the model MATsim which represents a software with the open-source code. This software allows to formulate the modules on the base of the agents for transportation scheduling. They also suggest using the simulators CEMDAP and STATPOP. These agent - based virtual reality simulators the scientists offer for the transport policy regulation oriented on the demand of the population [15].

In this paper the authors also want to give a brief description of the existing virtual reality facilities which are widely used in higher educational establishments of transport in the Russian Federation. According to the statistics data the most common accidents on 
railway result from the human error. The joint stock company "Russian Railways" see the huge potential in the methods of immersive technologies application. This potential can solve the problems concerning the safety and health protection as well as technic training of various railway manipulation performance. The technologies of virtual reality immersion are becoming nowadays a part of educational process paradigm due to the peculiarities of the transferred knowledge human perception. It solves one of the most difficult tasks of technical education that is the elimination of risks while working or operating the railway equipment. Such risks especially often occur in operation and maintenance of power supply equipment and facilities. In order to minimize the risks in the work of railway employees the scientists and lecturers of the Russian University of Transport (RUT MIIT) have developed the laboratory facilities with the application of virtual and augmented reality for the students studying in the field of the railway power supply. The university has developed the training complex for electrical engineers of the overhead wire. This simulator uses the technology of digital twin and is relevant for the manipulations in the field of occupational safety on railway. The simulator is equipped with the VR helmet and the controller of the virtual reality that allows to imitate a three-dimensional environment with the effect of deep immersion into technological atmosphere. This simulator of virtual reality allows to practice skills of working with the overhead wire in the extreme circumstances. Nowadays the facilities allowing to imitate the replacement of switches, the correction of subsidence and misalignment of the track, the study of the manipulation procedure in case of fire in trains exist and have been purchased. These simulators allow to train undergraduate specialists and bachelors in the field of automation and telemechanic, track and track facilities, mechanization on railway transport. The company «Zarnitza Technologies» has developed the virtual complex of locomotive drivers training, which is the training cab of the locomotive «VL80S». Every simulator cab of this type includes all necessary equipment plus the system "instructor-trainee" in order to avoid the incorrect usage of the simulator in the absence of the lecturer instructor.

As it is seen from the overview the laboratory facilities of reality simulators have become to be applied in the training of specialists rather lately. In connection with the new trends in the higher education Rostov State Transport University has also purchased the equipment that are the virtual facilities of reality simulators. This equipment has been installed in the rooms of the university and has been operated for several years already. These simulators are used for the undergraduate specialists and bachelors who study according to the programs of higher education implying the future employment on railway. For the experimental part of our research the group of students studying under the program of railway operation has been chosen.

The application VR simulators equipment for the improving of the educational quality at the technical university

\section{Results}

In order to improve the quality of education and professional training of future railway engineers, RSTU is equipped with several laboratory and simulator complexes represented in the table below.

Table 1. Types of simulator complexes of RSTU.

\begin{tabular}{|l|l|l|lr|r|r|}
\hline$№$ & $\begin{array}{l}\text { The } \\
\text { simulator } \\
\text { complex } \\
\text { name }\end{array}$ & $\begin{array}{l}\text { Characteristics of the } \\
\text { simulator } \begin{array}{l}\text { Advantages of the } \\
\text { knowledge, abilities and } \\
\text { skills to be developed }\end{array}\end{array}$ & $\begin{array}{l}\text { Disadvantages } \\
\text { simulator complex } \\
\text { of simulator } \\
\text { complex. }\end{array}$ \\
\hline 1. & Digital & Skills and abilities to work & In addition to & Local network \\
\hline
\end{tabular}




\begin{tabular}{|c|c|c|c|c|}
\hline & railway & $\begin{array}{l}\text { with information systems } \\
\text { and information software; to } \\
\text { make new and innovative } \\
\text { solutions; mastering new IT } \\
\text { technologies. }\end{array}$ & $\begin{array}{l}\text { theoretical knowledge, } \\
\text { practical knowledge and } \\
\text { skills are acquired that the } \\
\text { young specialist } \\
\text { previously obtained in } \\
\text { working conditions or in } \\
\text { the process of } \\
\text { independent work, which } \\
\text { required a significant } \\
\text { amount of working hours. }\end{array}$ & $\begin{array}{l}\text { connection } \\
\text { problems may } \\
\text { occur; a constant } \\
\text { need of software } \\
\text { updating }\end{array}$ \\
\hline 2. & $\begin{array}{l}\text { Virtual } \\
\text { railway }\end{array}$ & $\begin{array}{l}\text { Effective use of the } \\
\text { locomotive fleet and } \\
\text { locomotive crews; } \\
\text { locomotive running; } \\
\text { diagnostics of the permanent } \\
\text { way; acquaintance with the } \\
\text { specifics of the work of } \\
\text { operational personnel. }\end{array}$ & $\begin{array}{l}\text { The acquired skills } \\
\text { shorten the adaptation } \\
\text { period of the young } \\
\text { specialist to the working } \\
\text { conditions }\end{array}$ & $\begin{array}{l}\text { Regular } \\
\text { software } \\
\text { development in } \\
\text { accordance with } \\
\text { the actual routes } \\
\text { of JSC «Russian } \\
\text { Railways». }\end{array}$ \\
\hline 3. & $\begin{array}{l}\text { Electronic } \\
\text { Examiner }\end{array}$ & $\begin{array}{l}\text { Replacement of the } \\
\text { teacher-examiner for pre- } \\
\text { prepared questions. }\end{array}$ & $\begin{array}{l}\text { One of the simplest } \\
\text { computer simulators and } \\
\text { quite low in cost. }\end{array}$ & $\begin{array}{l}\text { Lack of } \\
\text { interaction } \\
\text { between teacher } \\
\text { and student. } \\
\end{array}$ \\
\hline 4. & $\begin{array}{l}\text { Console } \\
\text { simulators }\end{array}$ & $\begin{array}{l}\text { The simulator consists of a } \\
\text { computer and a control } \\
\text { panel, which can be either a } \\
\text { simplified version of the } \\
\text { control devices (control of } \\
\text { any part, for example, } \\
\text { control of switches) or an } \\
\text { exact copy of a real control } \\
\text { panel (a full-scale simulator, } \\
\text { for example, a real control } \\
\text { panel of a hump yard or } \\
\text { station master). All these } \\
\text { simulators allow you to } \\
\text { model the real processes } \\
\text { taking place at the station, } \\
\text { based on 3D graphics. }\end{array}$ & $\begin{array}{l}\text { These simulators allow } \\
\text { you to imitate emergency } \\
\text { situations (e.g. operations } \\
\text { on the slanted part of the } \\
\text { hump) }\end{array}$ & \begin{tabular}{l}
\multicolumn{2}{c}{ Complicated } \\
graphic design of \\
this type of \\
simulator; \\
malfunction in \\
the local \\
computer \\
network.
\end{tabular} \\
\hline 5. & $\begin{array}{l}\text { Static } \\
\text { simulators }\end{array}$ & $\begin{array}{l}\text { The main feature of these } \\
\text { simulators is the logical- } \\
\text { dynamic simulation of } \\
\text { complex situations in } \\
\text { complicated transportation } \\
\text { systems and the lack of } \\
\text { mathematical modeling of } \\
\text { processes. }\end{array}$ & $\begin{array}{l}\text { The student is given a } \\
\text { difficult situation and a } \\
\text { certain order of his or her } \\
\text { actions.is tested }\end{array}$ & $\begin{array}{l}\text { Some situations } \\
\text { may be extremely } \\
\text { difficult for } \\
\text { students. }\end{array}$ \\
\hline 6. & $\begin{array}{l}\text { Dynamic } \\
\text { simulators }\end{array}$ & $\begin{array}{l}\text { They are based on a } \\
\text { mathematical model of real } \\
\text { processes and consist of } \\
\text { standard elements built } \\
\text { according to a hierarchical } \\
\text { principle or using cyclic list. }\end{array}$ & $\begin{array}{l}\text { They allow you to } \\
\text { explore } \\
\text { operating modes and } \\
\text { analyze abnormal and } \\
\text { emergency situations. } \\
\text { Regular practice on these } \\
\text { simulators contributes to } \\
\text { the quality training of } \\
\text { future specialists. }\end{array}$ & \begin{tabular}{lr}
\multicolumn{2}{c}{ It is not always } \\
possible & to \\
simulate & an \\
emergency & \\
situation & \\
accurately. &
\end{tabular} \\
\hline 7. & $\begin{array}{l}\text { Training } \\
\text { simulators }\end{array}$ & $\begin{array}{l}\text { These simulators are based } \\
\text { on software models that are }\end{array}$ & $\begin{array}{l}\text { Training simulators at } \\
\text { RSTU are used by both }\end{array}$ & $\begin{array}{l}\text { Simulators } \\
\text { must fully }\end{array}$ \\
\hline
\end{tabular}




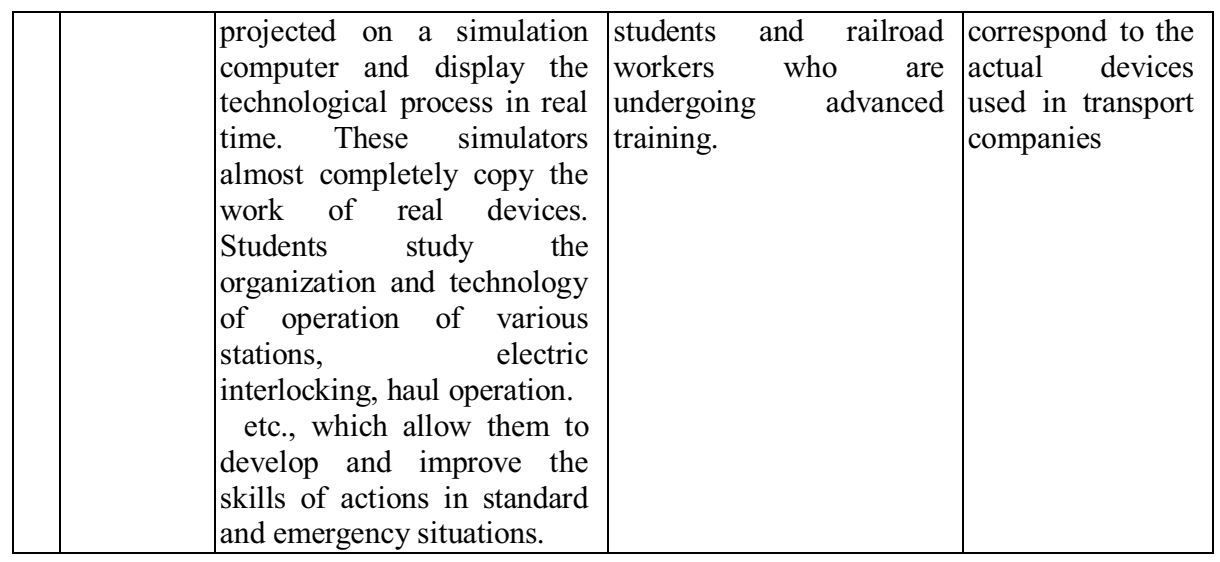

The practice of using a set of simulators in the process of education shows that they are an important element in the training of railway transport specialists. Knowledge, skills and abilities are practiced and improved in different circumstances, which almost accurately recreate the real working conditions and the real situation in various workplaces.

\section{Discussion}

Railway transport in Russia is one of the leading passengers and freight carriers. JSC "Russian Railways", being one of the largest transport companies, sets itself a number of tasks, including the development and successful implementation of new digital technologies (among them are projects: "Digital Railway", "Smart Locomotive", "Smart Train"); improvement of information service systems for railway transport customers and users; creation of an intelligent transport environment, etc.

Successful completion of the tasks is reached by qualified personnel, their knowledge, skills and abilities. The tasks and problems connected with railway specialists training are constantly discussed in educational institutions, working in this field of industry. Today, the vocational school is facing new requirements for training specialists.

RGUPS, along with other railway universities, is an educational platform for training future specialists for professional activities. As part of this work, the laboratory base of the Rostov State Transport University was analyzed, which serves as a powerful stimulator for improving the quality of training of students in the specialty "Railway Operation" and is fundamental in the formation of their professional competencies and additional skills.

Currently, in the conditions of intense competition, increasing globalization processes, the development of new market technologies and innovations, professional success is achieved by the specialist who does not only possess certain professional knowledge and skills, but also by the one who is able to work in the existing information space, successfully apply the acquired professional skills and show flexibility to the requests and requirements of both employers and participants in the transport environment.

The main goal of modern education is to train a qualified and competitive professional, who corresponds to world standards in the field of his/her professional activity, and is ready for professional development and growth.

Innovations and new technologies increase the requirements for training specialists. Other factors (social, psychological, etc.), which play an important role, are: responsibility, the ability to cooperate and work in a team, plan and rationally use working hours, analyze the problem and independently make decisions and carry out continuous professional education. 
The key factor in the success of educational activities and practical training of a specialist is the university's educational and laboratory base. It allows not only to form professional knowledge, skills and abilities, but also to perform specific functions related to the future profession and production activities.

Today, the transition to new standards in the education system entailed a revision of all educational and methodological complexes. In addition, some adjustments were aimed at improving the level of practical training of students, who along with mastering of basic courses included in the university programs, must find the application of the skills obtained, learn to analyze process and correctly use the information received, to master modern technology.

Specialists of this kind are of interest to the employer, since in the course of their studies at the university they develop the needs to expand knowledge and, thereby, improve professional competence.

Therefore, the training of a qualified specialist with these competencies is impossible without the presence of appropriate material and technical facilities. Training in laboratory classrooms contributes to the development of practical skills such as: controlling the movements of trains and shunting trains; working with signalling, centralization and interlocking devices; acting in auxiliary and emergency situations; preparing and executing technical documentation.

In our work, we have studied the relationship between the application of laboratory VR simulators on the railway and the quality of knowledge gained as a result of learning. We suggested that the above-described laboratory complexes considerably improve the quality of training at a technical university in specialties: "Mainline transport" (MT student group), "Freight and commercial operation" (FCO student group), "Transport and business logistics" (TBL student group), "Passenger complex of railway transport" (PCRT student group).

To confirm our hypothesis, we used the method of processing statistical data, namely, "T student criterion". We analyzed the final test results on the professional knowledge, skills and abilities of the control group of 5th-year students in the specialties of MT, FCO, TBL, PCRT who study at department Railway management and operation. These students studied in 2020 (this year VR simulators were used) and 2018 (the year when laboratory complexes of VR were not used in the educational process). The results are presented in Figure 1, where the percentage of correct answers of graduates in 2018 is shown in red, and the percentage of answers of 2020 graduates is shown in green.

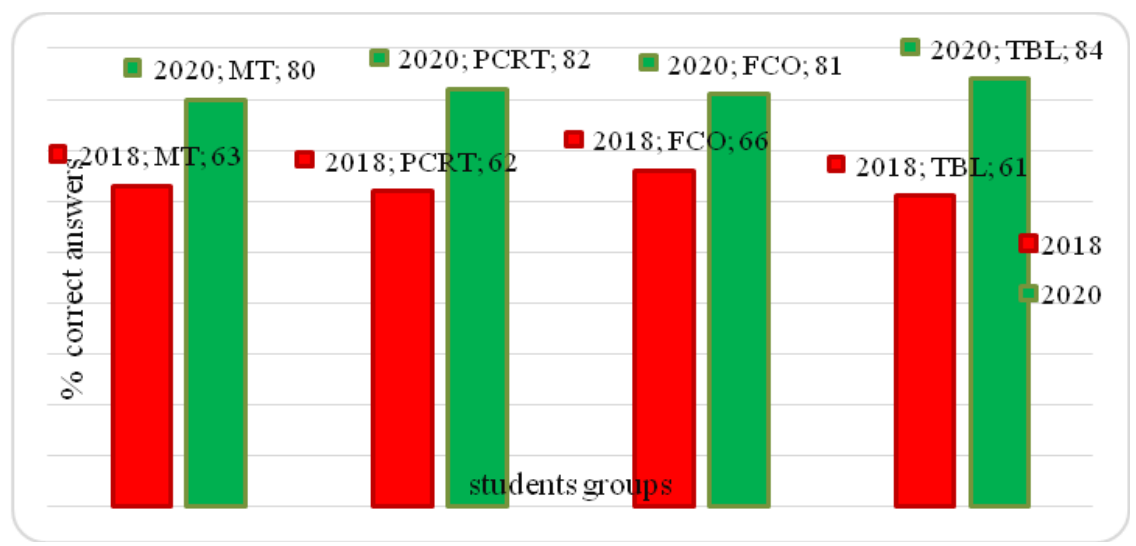

Fig. 1. Percentages of the final testing results of the students graduated in 2018 and 2020. 
After calculating the results, we can confirm with a high degree of probability that, indeed, the use of virtual reality simulators positively affects the results of training students in railway specialties at a technical university and considerably improves the quality of professional training of a railway engineer.

\section{Conclusion}

The development of the transport industry and the extension of the transport infrastructure greatly influence the formation and educational policy of transport universities on the one hand, and on the other - the development of new IT technologies, modern scientific research and new innovative solutions. Possession of new information technologies, together with the skills and abilities to work on modern equipment, constitute the professional training of a railway engineer.

There is a peculiarity in training of such specialists. It is not enough for graduates to have only theoretical knowledge; they must possess skills and abilities that could previously be acquired only during an internship or in the workshop environment, which was time-consuming.

The use of digital information technology in higher education contributes to the acquiring of skills and abilities that help a young specialist to adapt to the working conditions in the shortest possible time and reduce the cost of his training. This is the purpose of modernization of the RSTU laboratory base that is guided by Russian Railways' information policy and strategy for the development of information technologies.

The learning process is built on the basis of simulators and programs with the use of active teaching methods such as business games and programmed training. Classrooms with computer-based workplaces connected by a local information network make the situation as close as possible to the real conditions in the transport sphere.

This study analyzes the existing laboratory base of RSTU, identifies the main laboratory complexes and software that are used in the training of railway engineers.

The data given in the article underlines that digital technologies have penetrated deeply into the field of education, generating new pedagogical methods and strategies in the educational process. The conducted research leads to the conclusion that the simulator complexes of virtual reality have confirmed their relevance and validity as a pedagogical technique, allowing to improve the quality of the educational process and significantly extend the teacher's pedagogical portfolio. We can identify a number of features that arise from the peculiarities associated with the use of VR simulators at the technical university:

- The use of virtual reality simulators implies that students have fundamental knowledge of the subject.

- The teacher's role and behavioral strategy is transformed from the initiator of the educational process to the observer and corrector of the processes occurring in the simulator.

- VR simulators have a stronger impact on the sensory modality of the learner.

- The application of virtual reality simulators should take into account the age and psychological features of the students.

- The material selection for working with virtual and augmented reality simulators should be relevant to the learning situation.

- The use of digital technologies should not be the goal in itself, the final product of education still depends on the environment and pedagogically valid teaching methods

- The use of VR techniques in the training of technical university students significantly reduces the cost of conducting the experimental part of the educational process compared to the real conditions of the experiment. 
- Complexes of VR simulators used in the educational process make it possible to minimize the risks of hazardous work, which can take place in real life, allow improving working conditions and the labor safety system at work.

- The negative aspect of simulator complexes using is the emotional state of students in different operating modes, and in some situations inaccessibility and lack of interaction between students.

\section{References}

1. Average time spent by Indians on smartphones highest globally: Nokia report (Feb 11, 2021) Available at: https://timesofindia.indiatimes.com/business /indiabusiness/average-time-spent-by-indians-on-smartphones-highest-globally-nokiareport/articleshow/80860093.cms.. (accessed 10 March 2021).

2. R.A. Rasi, K.M. Ashifa, J. Anu, Badu Vengal Cinniya, Materials Today: Proceedings. (2020), https://doi.org/10.1016/j.matpr.2020.10.133

3. C. Stokel-Walker, Us vs the gadgets (NewScientist, 2019). https://doi.org/10.1016/S0262-4079(19)30831-0

4. $21^{\text {st }}$ Century Skills. Available at: http://21stcenturyskillsbook.com/resources/ (accessed 10 March 2021).

5. S. Al Awadhi, N. Al Habib, D. Murad, F. Al Deei, M. Al Houti, T. Beyrouthy, et al.: Virtual reality application for interactive and informative learning, 2017 2nd international conference on bio-engineering for smart technologies, 1-4, (2017). IEEE.

6. D. Cortiz, J. Silva, Web and virtual reality as platforms to improve online education experiences, 2017 10th international conference on human system interactions, pp. 8387 (2017). IEEE.

7. M. Misbhauddin, VREdu, A framework for interactive immersive lectures using virtual reality, 2018 21st Saudi computer society national computer conference, 1-6 (2018). IEEE.

8. D. Shattuck, Healthcare Technology Letters 5 (5), 183-188 (2018).

9. M. Pacilli, S. Clarke, Seminars in Pediatric Surgery 29 (2), (2020). https://doi.org/10.1016/j.sempedsurg.2020.150905

10. M. Crozier, H. Ting, M. Darrell, C. Boone, M. Noel, A Multidisciplinary Team Assessment Tool in Trauma Education.Journal of Surgical Education 72 (1), (2014). https://doi:10.1016/j.jsurg.2014.07.009

11. R. Martinou, G. Chindambaran, A. Krishnasamy, S. Donnell, G. Vig, International Journal of Surgery 1 (23), (2015).https://doi.org/10.1016/j.ijsu.2015.07.477

12. A. Burden, Anesthesiology Clinics 4 (28), https://doi.org/10.1016/j.anclin.2020.08.006

(2020).

13. P. Hallingerab, R. Wang, The International Journal of Management Education 3 (18), (2020) https://doi.org/10.1016/j.ijme.2020.100418

14. J. Camaj, M. Kendra, J. Lalinská, Procedia - Social and Behavioral Sciences 176, (2015). https://doi:10.1016/J.Sbspro.2015.01.524

15. D. Ziemke, B. Charlton, S. Horl, K. Nagel, Transportation Research Procedia 52, 613620 (2021). https://doi.org/10.1016/j.trpro.2021.01.073

16. J. Radianti, T. Majchrzak, J. Fromm, I. Wohlgenannt, Computers \& Education 147 (2020).https://doi.org/10.1016/j.compedu.2019.103778 
17. J. Wang, E.H. Dineke, Tigelaar, W. Admiraal, Computers \& Education. Computers \& Education 161 (2021). https://doi.org/10.1016/j.compedu.2020.104055

18. I. Nefedov, The Russian Language teaching methods 4, (2019). DOI: 10.24411/18111629-2019-14061

19. A. Bahmudova, A. Bahmudov, Science Prospects 4 (115), 188-190(2019).

20. K. Fedorov, A. Nikonorov, Professional education and HR market 2, 30-31(2016). 